\title{
Cloning and sequencing of a gene encoding acidophilic amylase from Bacillus acidocaldarius
}

\author{
Teija T. Koivula, ${ }^{1}$ Harri Hemilä, ${ }^{2}$ Raimo Pakkanen, ${ }^{3}$ Mervi Sibakov ${ }^{4}$ and Ilkka Palva ${ }^{5 *}$ \\ ${ }^{1,2}$ Departments of Genetics ${ }^{1}$ and Public Health, ${ }^{2}$ University of Helsinki, Helsinki, Finland \\ ${ }^{3}$ Valio Bioproducts Ltd, Turku, Finland \\ ${ }^{4}$ Valio Ltd, Helsinki, Finland \\ ${ }^{5}$ Agricultural Research Center, Jokioinen 31600, Finland
}

(Received 13 November 1992; revised 19 March 1993; accepted 19 April 1993)

\begin{abstract}
Two starch-degrading enzymes produced by Bacillus acidocaldarius (renamed as Alicyclobacillus acidocaldarius) were identified. According to SDS-PAGE, the apparent molecular masses of the enzymes were 90 and $160 \mathrm{kDa}$. Eight peptide fragments and the $\mathrm{N}$-terminal end of the $90 \mathrm{kDa}$ polypeptide were sequenced. An oligonucleotide, based on the amino acid sequence of a peptide fragment of the $90 \mathrm{kDa}$ protein, was used to screen a $\lambda \mathrm{gt10}$ bank of $B$. acidocaldarius, and the region encoding the $90 \mathrm{kDa}$ protein was cloned. Unexpectedly, the ORF continued upstream of the $\mathrm{N}$ terminus of the $90 \mathrm{kDa}$ protein. The entire ORF was 1301 amino acids (aa) long (calculated molecular mass $140 \mathrm{kDa}$ ) and it was preceded by a putative ribosomal binding site and a promoter. Computer analysis showed that the $\mathbf{1 3 0 1}$ aa protein was closely related to an $\alpha$-amylase-pullulanase of Clostridium thermohydrosulfuricum. We suggest that the starch-degrading $160 \mathrm{kDa}$ protein of $B$. acidocaldarius is an $\alpha$ amylase-pullulanase, and the $90 \mathrm{kDa}$ protein is a cleavage product of the $160 \mathrm{kDa}$ protein. Another ORF, apparently in the same transcription unit, was found downstream from the amylase gene. It encoded a protein that was closely related to the maltose-binding protein of Escherichia coli.
\end{abstract}

\section{Introduction}

Many Bacillus spp. produce starch-hydrolysing enzymes, including $\alpha$-amylases which are of great importance industrially (Vihinen \& Mäntsälä, 1989). $\alpha$-Amylases hydrolyse the internal $\alpha$-1,4-glucosidic linkages of starch at random. Usually, the $\alpha-1,6-$ linkages are not hydrolysed by the $\alpha$-amylases, but the enzymes can bypass the $\alpha-1,6$-linkages and produce branched dextrins in addition to linear oligosaccharides as end-products. However, certain $\alpha$-amylases can also hydrolyse $\alpha$-1,6-glucosidic linkages (Sakano et al., 1985).

Bacillus acidocaldarius (renamed as Alicyclobacillus acidocaldarius; Wisotzkey et al., 1992) grows in acidic and hot conditions $\left(60-70^{\circ} \mathrm{C}\right)$ and therefore it is a potential source of exoenzymes which are active at low $\mathrm{pH}$ and/or high temperature. B. acidocaldarius ATCC 27009 produces a starch-degrading enzyme which

*Author for correspondence. Tel. 1688270 ; fax 1684550 .

The nucleotide sequence data reported in this paper have been submitted to the EMBL and assigned the accession number $\mathrm{X} 62835$. has been partially characterized. It is a thermoacidophilic endoamylase with a $\mathrm{pH}$ optimum of 4.5 and temperature optimum of $60-63^{\circ} \mathrm{C}$ (Boyer et al., 1979). The enzyme is not released to growth medium, but has been extracted from plate cultures (Boyer et al., 1979). Three other thermophilic and acidophilic starch-degrading enzymes have been characterized from Bacillus spp. These enzymes have been isolated from $B$. acidocaldarius strains Agnano 101 (Buonocore et al., 1976) and A-2 (Kanno, 1986), and from Bacillus sp. 11-1S (Uchino, 1982). The $\mathrm{pH}$ optima of the three enzymes ranged from 2.0 to $3 \cdot 5$, temperature optima between 70 and $75{ }^{\circ} \mathrm{C}$ and apparent molecular masses from 54 to $68 \mathrm{kDa}$. The molecular mass of the $B$. acidocaldarius ATCC 27009 amylase has not been determined. Thus far none of the genes encoding these four proteins have been cloned and sequenced. Essentially, all industrially important bacterial $\alpha$ amylases have their $\mathrm{pH}$ optima close to neutral. However, some processes (e.g. silage treatment) require enzymes that are active at low $\mathrm{pH}$ and therefore there is also a need for acidotolerant enzymes. In this paper we describe the cloning and characterization of the gene encoding the thermoacidophilic amylase of $B$. acidocaldarius. 


\section{Methods}

Bacterial strains, plasmids and culture conditions. B. acidocaldarius ATCC 27009 was obtained from the American Type Culture Collection (Rockville, MD, USA). The culture was grown on solid medium for enzyme preparation, and in liquid medium for DNA isolation (Darland \& Brock, 1971). Escherichia coli $\mathrm{DH} 5 \alpha \mathrm{F}^{\prime}$ was used as a cloning host for M13mp18, M13mp19, pUC19 and pBR322-based DNA constructions which were made for sequencing. $E$. coli strains were grown in Luria broth supplemented with ampicillin $\left(100 \mu \mathrm{g} \mathrm{ml}^{-1}\right)$.

Enzyme assays. The Phadebas amylase test (for food applications, unbuffered; Pharmacia) was used for quantitative amylase activity measurements. The Phadebas test is based on a blue insoluble polysaccharide polymer, which is broken down by amylase thus releasing the blue colour. A plate assay was used for rapid screening of amylase activity. In this assay samples were applied into $4 \mathrm{~mm}$ wells made in agar plates containing $0.2 \%$ soluble starch (Merck), $20 \mathrm{mM}$ $\mathrm{CaCl}_{2}, 50 \mathrm{~mm}-\mathrm{Na}$ acetate (pH 5.0) and $1.5 \%$ (w/v) agar (Difco). The plates were incubated at $55^{\circ} \mathrm{C}$ for $2-10 \mathrm{~h}$ and starch degradation was detected by spreading $10 \mathrm{~mm}-\mathrm{KI} / \mathrm{I}_{2}$ solution on the plates. Zymography was used for the detection of amylase activity in SDS-polyacrylamide gels (Laemmli, 1970) as follows. After SDS-PAGE, the gel was washed in $50 \mathrm{mM}-\mathrm{Na}$ acetate (pH 5.0) for $15 \mathrm{~min}$ and laid onto a starch-agar plate. The plate was incubated at $55^{\circ} \mathrm{C}$ for $10 \mathrm{~h}$ and the amylase activity was detected by staining the plate with $10 \mathrm{mM}-\mathrm{KI} / \mathrm{I}_{2}$ solution.

The pullulanase assay was based on the Somogyi-Nelson method (Nelson, 1944; Somogyi, 1952) that detects the quantity of reducing sugars released during the hydrolysis of pullulan. The reaction mixture contained $0.5 \%$ pullulan (Sigma) in $0.15 \mathrm{~mm}-\mathrm{Na}$ acetate buffer (pH 5.0 ) and $5 \mathrm{~mm}-\mathrm{CaCl}_{2}$. The reaction was allowed to proceed at $55^{\circ} \mathrm{C}$ except in the case of temperature optimum determination where the reaction temperature varied from 25 to $75^{\circ} \mathrm{C}$. The pullulan plate assay was used for rapid screening of pullulanase activity. The pullulan plates were similar to the starch plates but $0.2 \%$ pullulan was added instead of starch. Samples were applied onto the pullulan plates and incubated at $55^{\circ} \mathrm{C}$ for $18 \mathrm{~h}$. Pullulan degradation was detected by spreading the plates with $94 \%(\mathrm{v} / \mathrm{v})$ ethanol, followed by incubation at $4{ }^{\circ} \mathrm{C}$ for $2-4 \mathrm{~h}$. Transparent haloes around the holes, against the white background, indicated pullulan hydrolysis.

Purification of the enzyme and determination of peptide sequences. Plate cultures of $B$. acidocaldarius were suspended in $0.5 \mathrm{M}-\mathrm{Na}$ acetate (pH 5.0), incubated for $30 \mathrm{~min}$ at $4^{\circ} \mathrm{C}$, and the cells were removed by centrifugation at $8000 \mathrm{~g}$ for $20 \mathrm{~min}$. The supernatant was centrifuged again at $40000 \mathrm{~g}$ for $30 \mathrm{~min}$ and proteins of the cleared medium were precipitated at $0{ }^{\circ} \mathrm{C}$ for $30 \mathrm{~min}$ by slow addition of $\left(\mathrm{NH}_{4}\right)_{2} \mathrm{SO}_{4}$ to a final concentration of $70 \%(\mathrm{w} / \mathrm{v})$. The precipitate was collected by centrifugation at $10000 \mathrm{~g}$ for $20 \mathrm{~min}$. The pellet was dissolved in $20 \mathrm{~mm}$-Bis-Tris (pH 5.8), applied onto a Bio-Gel P-200 (Sigma) column $(1.5 \times 45 \mathrm{~cm})$, and eluted with the same buffer. Fractions containing amylase activity were pooled and concentrated by ultrafiltration in a Novacell-Omegacell apparatus (Filtron). The concentrate was rechromatographed in a Superose 12 HR 10/30 column (Pharmacia, Sweden) in $20 \mathrm{~mm}$-Bis-Tris (pH 5.8). Fractions containing amylase were concentrated as above. The proteins were further separated by $10 \%$ SDSPAGE. The gel was treated with $1 \mathrm{M}-\mathrm{KCl}$ to visualize protein bands and the band corresponding to the amylase activity was excised. The protein was electoeluted from the gel using an ISCO model 1750 electrophoretic concentrator as described elsewhere (Kalkkinen, 1986). The eluate was freeze-dried and the solid material was dissolved in $50 \mathrm{~mm}$-Tris/ $\mathrm{HCl}$ ( $\mathrm{pH} \mathrm{9 \cdot 0)}$ ). Lysylendopeptidase (Wako) was added to a final concentration of $3 \mu \mathrm{g} \mathrm{ml}^{-1}$ and the mixture was incubated at $30^{\circ} \mathrm{C}$ for $18 \mathrm{~h}$. The resulting peptides were separated by reverse phase chromatography on a Vydack 218 TPB5 $(0.46 \times 15 \mathrm{~cm})$ column connected to a Varian 5000 liquid chromatograph. The peptides were eluted using a linear gradient of acetonitrile (0-60\% in $90 \mathrm{~min})$ in $0.1 \%$ trifluoroacetic acid.

For N-terminal amino acid sequence analysis, amylase was transferred electrophoretically onto a polyvinylidene difluoride membrane (Mozdzanowski \& Speicher, 1990) and sequenced in a gas/pulsedliquid sequencer (Kalkkinen \& Tilgmann, 1988). The purified peptides from the lysylendopeptidase digestion were applied on polybrene pretreated fibreglass filters and sequenced.

Determination of the isoelectric point. Chromatofocusing was performed using Mono P 5/20 column according to the manufacturer's instructions (Pharmacia). $\alpha$-Amylase activity and $\mathrm{pH}$ of each fraction was measured. Isoelectric focusing was done on $1 \%$ agarose gels containing $\mathrm{pH}$ 3-10 ampholyte (Pharmacia). The enzyme activity was detected by zymography. In isoelectric focusing, standard proteins (pI range 3.5-9.3) by Pharmacia were used. For isoelectric point determinations the enzyme was eluted from the $B$. acidocaldarius cells by $\mathrm{Na}$ acetate and precipitated by $\left(\mathrm{NH}_{4}\right)_{2} \mathrm{SO}_{4}$ (see above).

Determination of $\mathrm{pH}$ optimum. Enzyme activity of the $\mathrm{Na}$ acetateeluted proteins of $B$. acidocaldarius cultures was measured using the Phadebas amylase test at 37 and $60^{\circ} \mathrm{C}$ in $0.1 \mathrm{M}$-citric acid, $0.2 \mathrm{M}$ $\mathrm{Na}_{2} \mathrm{HPO}_{4}$. The $\mathrm{pH}$ range was 2-7 in steps of $1 \mathrm{pH}$ unit.

DNA methods and sequence analysis. The $\lambda \mathrm{gt} 10$ gene bank of $B$. acidocaldarius ATCC 27009 chromosomal DNA was constructed as follows. Chromosomal DNA from $B$. acidocaldarius was isolated according to Marmur (1961). The DNA was digested partially with HaeIII. DNA fragments of 5.0 to $6.5 \mathrm{~kb}$, collected from an agarose gel, were methylated with $E c o$ RI methylase and ligated to EcoRI linkers, and inserted into $E c o$ RI-digested $\lambda$ gt 10 using Amersham cDNA cloning system according to the instructions of the supplier.

Hybridizations were done as described previously (Koivula et al., 1991). Sequencing was performed by the method of Sanger et al. (1977) and both strands were sequenced. The oligonucleotides (Table 1) were synthesized with an Applied Biosystems DNA-synthesizer Model 381A. Plasmid purifications, DNA digestions and other DNA manipulations were performed according to established methods (Sambrook et al., 1989).

The nucleotide sequences derived from sequencing gels were assembled with the ASSEMGEL program of the PCGENE sequence analysis package (Intelligenetics). Protein sequence databases were searched with the FASTA program (Pearson \& Lipman, 1988). Amino acid sequences were aligned with the BESTFIT program of the GCG package (Devereux et al., 1984).

\section{Results and Discussion}

\section{Characterization and purification of the thermoacidophilic amylase of $B$. acidocaldarius}

Previously, no amylase activity had been observed in culture supernatant when $B$. acidocaldarius was grown in liquid culture, but amylase activity could be released from cells grown on plates by washing with $0.5 \mathrm{M}-\mathrm{Na}$ acetate buffer (pH 5.0) (Boyer et al., 1979). This suggests that the protein is associated with the cytoplasmic membrane or cell wall at least under the growth conditions tested. We also isolated amylase activity by washing cells grown on plates. The proteins eluted from $B$. acidocaldarius cells by $0.5 \mathrm{M}-\mathrm{Na}$ acetate were precipitated with $\left(\mathrm{NH}_{4}\right)_{2} \mathrm{SO}_{4}$, subjected to SDS-PAGE and 


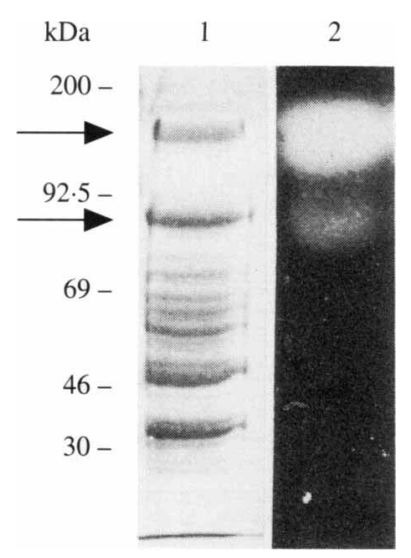

Fig. 1. SDS-PAGE of the $\left(\mathrm{NH}_{4}\right)_{2} \mathrm{SO}_{4}$-precipitated proteins. Lanes 1 and 2 represent a Coomassie Brilliant Blue-stained gel and zymogram, respectively. The arrows indicate the positions of the bands corresponding to amylase activity. The sizes of the molecular mass markers (Pharmacia) are indicated on the left.

analysed by zymography. This assay revealed two bands with apparent molecular masses of 90 and $160 \mathrm{kDa}$ (Fig. 1). The same bands of starch degradation were observed when SDS-PAGE was performed under non-reducing conditions (data not shown). Therefore, the $160 \mathrm{kDa}$ form was apparently not a disulphide-linked dimer of the $90 \mathrm{kDa}$ form. The amount of protein in the $90 \mathrm{kDa}$ and $160 \mathrm{kDa}$ bands was approximately the same, yet the starch-degrading activity of the $160 \mathrm{kDa}$ protein was much higher (Fig. 1). Thus, the $160 \mathrm{kDa}$ form appears to have a much higher specific activity, assuming that both proteins are refolded with similar efficiency. Several attempts to separate the proteins by chromatography failed due to low expression levels and poor recoveries of the proteins. In chromatofocusing and isoelectric focusing followed by zymography, the $90 \mathrm{kDa}$ and $160 \mathrm{kDa}$ polypeptides were detected as a broad peak and a band, respectively, at pI 4.8 (data not shown). The measurement of amylase activity of the cell wash medium at different $\mathrm{pH}$ gave a symmetric curve with a relatively sharp optimum at approximately $\mathrm{pH} 4.8\left(\right.$ at $60^{\circ} \mathrm{C}$ ). The optimal $\mathrm{pH}$ reported by Boyer et al. (1979) was 4.5. The amylase activity was fourfold higher at $60^{\circ} \mathrm{C}$ than at $37^{\circ} \mathrm{C}$. According to Boyer et al. (1979) the optimal temperature for the amylase was $60-63^{\circ} \mathrm{C}$.

The relationship between the $90 \mathrm{kDa}$ and $160 \mathrm{kDa}$ amylases was not clear. The results obtained by chromatofocusing and isoelectric focusing are consistent with the possibility that the two amylases may either be closely related or the smaller amylase could be a breakdown product of the larger. The molecular mass of the $B$. acidocaldarius ATCC 27009 amylase had not been determined previously but the protein was retained by a $30 \mathrm{kDa}$ cut-off membrane (Boyer et al., 1979). The molecular mass of the amylases from two other $B$. acidocaldarius strains has been shown to be approximately $67 \mathrm{kDa}$ (Buonocore et al., 1976; Kanno, 1986).

\section{Peptide sequences from the purified $90 \mathrm{kDa}$ polypeptide}

SDS-PAGE was performed to separate the $90 \mathrm{kDa}$ and $160 \mathrm{kDa}$ proteins for $\mathrm{N}$-terminal sequence analysis, but only the $90 \mathrm{kDa}$ protein could be purified in sufficient amounts. The separated protein was electrotransferred onto a polyvinylidene difluoride membrane and sequenced. A single amino acid sequence of Asp-Ile-AsnAsp-Tyr (DINDY) was obtained. Furthermore, eight peptides cleaved by lysylendopeptidase from the $90 \mathrm{kDa}$ protein were purified and sequenced (Fig. 2). The sequences of the peptides were determined to design oligonucleotide probes for the cloning of the gene.

\section{Cloning of the amylase-encoding region}

The amylase-encoding region was cloned as two fragments: $\mathrm{C}$ fragment and $\mathrm{N}$ fragment (Fig. 3). First, the $\mathrm{C}$ fragment was cloned from a $\lambda$ gt10 gene bank of $B$. acidocaldarius chromosomal DNA by plaque hybridization. The oligonucleotide 371 (Table 1) was synthesized according to the deduced DNA sequence of one of the lysylendopeptidase-cleaved peptides (Table 1, Fig. 2). It hybridized with six plaques out of 7000 screened. Restriction enzyme digestions of the DNA revealed that the inserts of four clones were of the same size $(4 \cdot 3 \mathrm{~kb})$. One of the cloned regions was sequenced from M13based constructs. According to the sequence, the cloned region ( $\mathrm{C}$ fragment) was $4.2 \mathrm{~kb}$ long and contained an ORF of 1177 amino acids (aa) with no complete $N$ terminus (Figs 2 and 3). In the middle of the fragment the amino acid sequence DINDY, the $\mathbf{N}$ terminus of the $90 \mathrm{kDa}$ protein, could be recognized (bp 4692, Fig. 2). The size of the polypeptide, deduced from the DNA sequence, starting with DINDY is $92 \mathrm{kDa}$; hereafter the smaller amylase is designated the $92 \mathrm{kDa}$ amylase. However, the ORF continued to the $5^{\prime}$ end of the $\mathrm{C}$ fragment, which indicated that the $92 \mathrm{kDa}$ amylase is most probably a cleavage product of a larger protein.

The $\mathrm{N}$ fragment was thereafter cloned from the $\lambda$ bank. One clone out of 6000 was found to hybridize with oligonucleotide 393, but not with oligonucleotide 395 (Table 1). This clone contained two EcoRI fragments, $3 \cdot 5$ and $1 \cdot 1 \mathrm{~kb}$ in size. The $1 \cdot 1 \mathrm{~kb}$ fragment was part of the $\mathrm{C}$ fragment but the $3.5 \mathrm{~kb}$ fragment was not (cf. Fig. 3). The nucleotide sequence of the $3.5 \mathrm{~kb}$ fragment $(\mathrm{N}$ fragment) was determined. According to the sequence, the $\mathrm{N}$ fragment was $3.7 \mathrm{~kb}$ long and contained a short ORF of 123 codons at the $3^{\prime}$ end. The reading frame of 


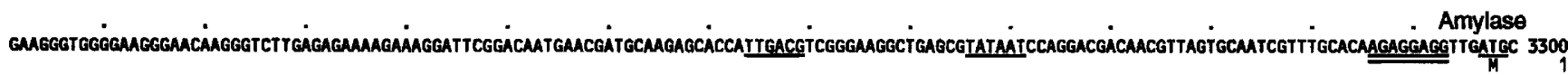

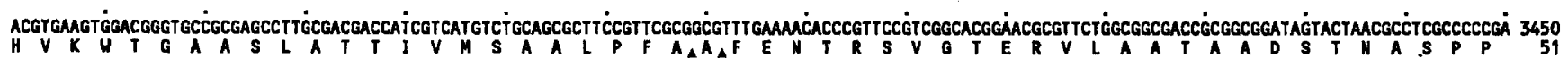

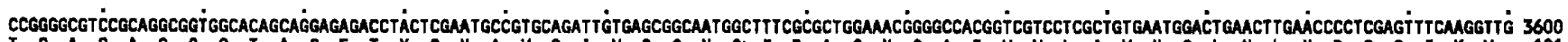
$T E A S A G G G T A G E T Y S N A V Q I V S G N G F R A G N G A T V V L A V N G L N L N P S S F K V A 101$

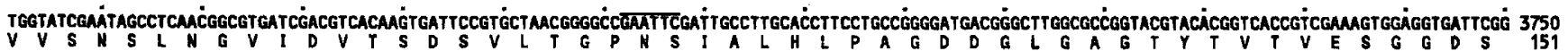

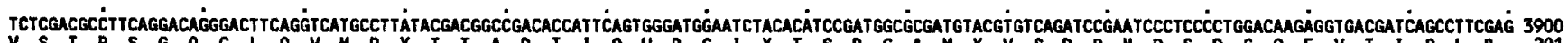

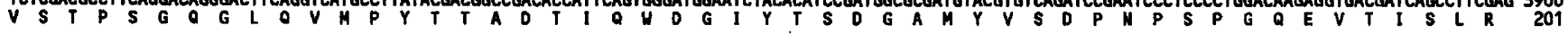

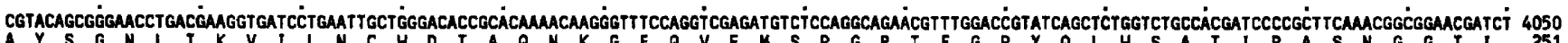
$A$ Y S G N L T K V I L N C W D T A Q N K G F Q VE M S P G R T F G P Y Q L W S A T I P A S N G G T I 251

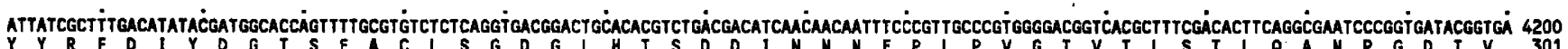
Y Y R F D I Y D G T S F A C L S G D G L H T S D D I N N N F P L P V G T V T L S T L Q A N P G D T V 301

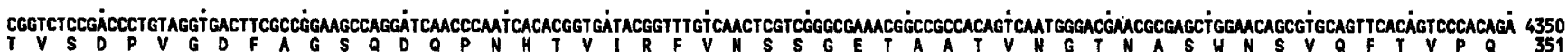
T VS D P V G D F A G S Q D O P N H T V I R F V N S S G E T A A T V NG T N A S H N S V A F T P Q 351

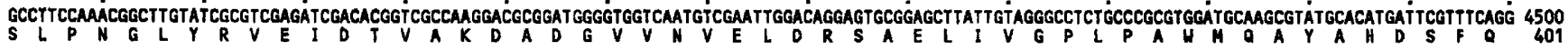

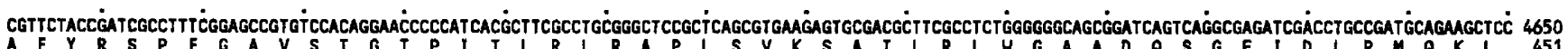
A F Y R S P F G A V S T G T P I T L R L R A P L S V K S A T L R L W G A A D Q S G E I D L P M Q K L 451

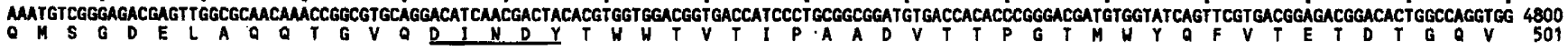

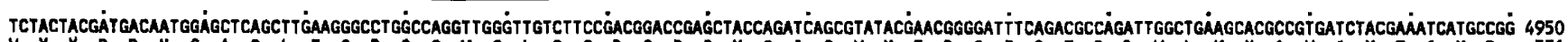
$V Y Y D D N G A Q L E G P G Q V G L S S D G P S Y Q I S V Y E R G F Q T P D W L K H A V I Y E I M P$

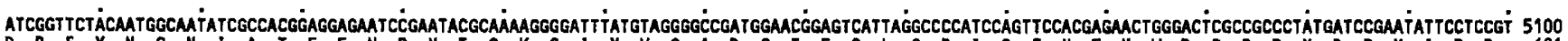

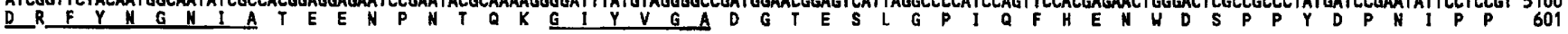

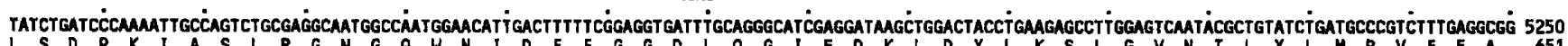

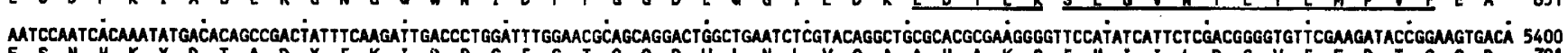

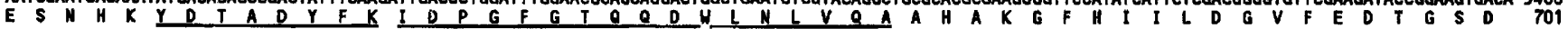

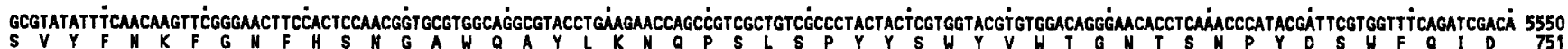

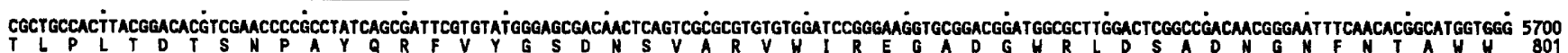

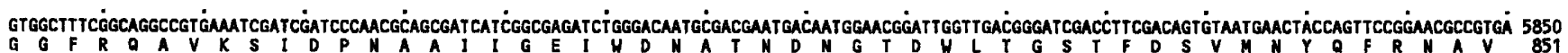

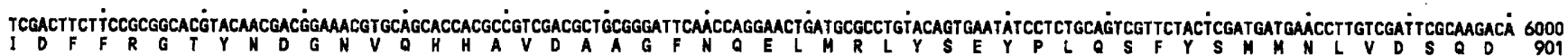

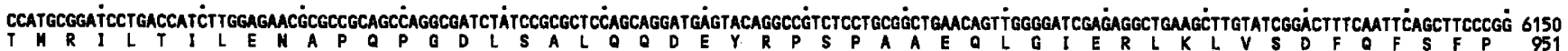

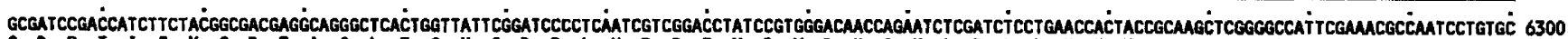

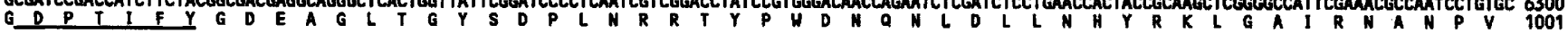

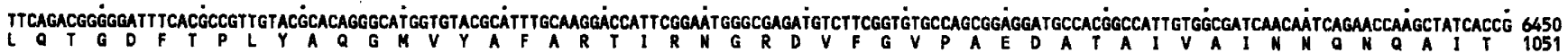

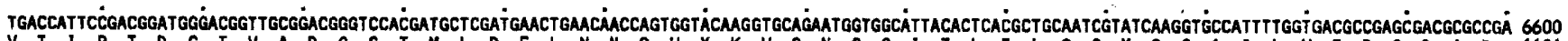
$V T I P T D G T V A D G S T M L D E L N N G W Y K V Q N G G I T L T L Q S Y Q G A I L V T P S D A P T 101$

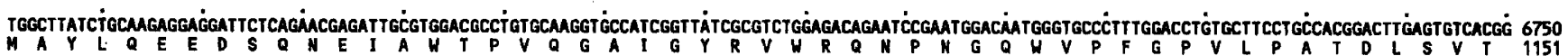

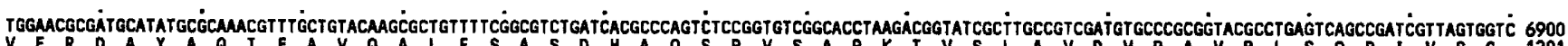
$V E R D A Y A Q T F A V Q A L F S A S D H A Q S P V S A P K T V S L A V D V P A V R L S Q P I V S G C 1201$

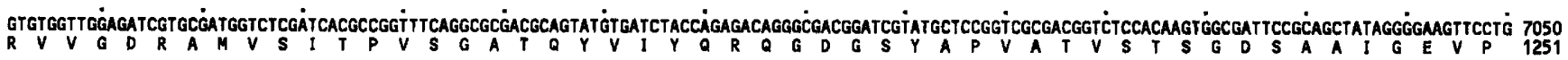

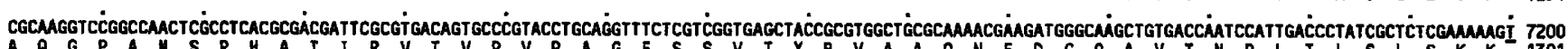

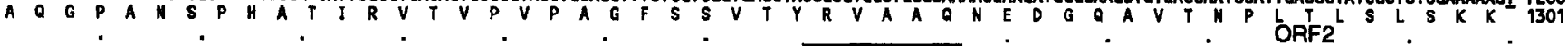

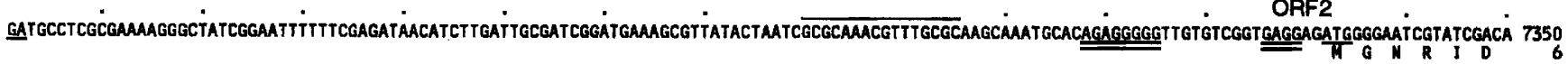

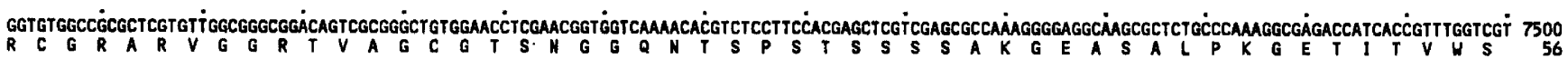

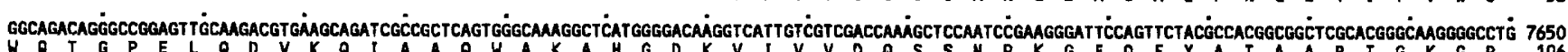
W T T G E L O D V K Q I A A Q W A K A H G D K V I V V D Q S S N P K G F Q F Y A T A A R T G K G P I06

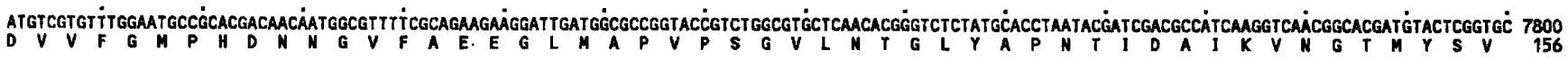

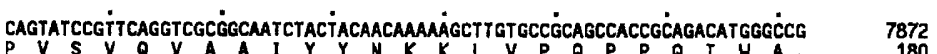

Fig. 2. Nucleotide sequence and the deduced amino acid sequence of the $B$. acidocaldarius amylase gene. The putative promoter, initiation codon and termination codon are underlined. The RBSs are indicated by double underlining. The deduced amino acid sequence is shown below the nucleotide sequence. Stretches of the amylase that were determined by peptide sequencing are underlined; in the case of an undefined aa in the peptide sequence, a short gap in the line is left under the residue. The putative signal sequence cleavage sites of the amylase are indicated with arrowheads. The EcoRI site, at bp 3662, marking the junction of the $\mathrm{N}$ and $\mathrm{C}$ fragments, and the 16 bp palindrome upstream of ORF2, are marked by a line above the sequence. 


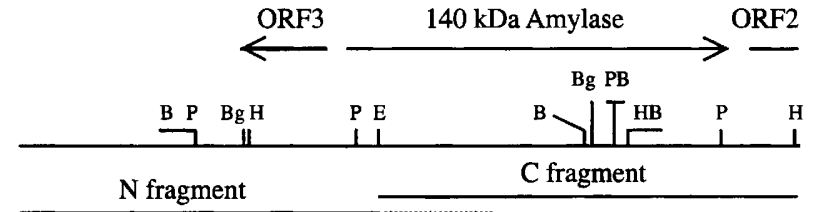

\section{$1 \mathrm{~kb}$}

Fig. 3. The structure of the cloned region. The $E c o$ RI site (E) is located at the junction of the $\mathrm{N}$ and $\mathrm{C}$ fragments. The $1 \cdot 1 \mathrm{~kb}$ fragment adjacent to the $\mathrm{N}$ fragment is indicated by a dotted line. The major ORFs are indicated with arrows. Restriction enzyme sites used in Southern blotting are indicated: B, BamHI; P, PstI; Bg, BglI; H, HindIII.

the ORF matched the reading frame of the 1177 aa ORF of the $\mathrm{C}$ fragment (Figs 2 and 3 ).

Two approaches were used to verify that the separately cloned $\mathrm{N}$ and $\mathrm{C}$ fragments were colinear in the $\boldsymbol{B}$. acidocaldarius chromosome and that they had been cloned without rearrangments. First, PCR with oligonucleotides 417 and 436 (Table 1) was used to isolate the region joining the $\mathrm{N}$ and $\mathrm{C}$ fragments from the chromosome. A fragment of $1 \mathrm{~kb}$ was obtained and the
DNA sequence was identical with the previously determined joint region. Second, Southern hybridization was used to confirm that there were no rearrangements within the whole sequenced region (data not shown, for enzymes used in digestions, see Fig. 3).

\section{Nucleotide sequence of the amylase gene}

The entire sequenced region was 7872 bp long (Fig. 2). The coding region for the amylase was $3903 \mathrm{bp}$, corresponding to a protein of 1301 aa (Fig. 2). Four basepairs upstream from the putative translation initiation codon (at bp 3297) a sequence similar to the $3^{\prime}$ end of the 16S rRNA of B. subtilis was recognized and this could serve as a ribosomal binding site (RBS). Further upstream a putative promoter, with -35 (TTGACG) and - 10 (TATAAT) regions, was found.

The molecular mass of the protein encoded by the $\mathrm{ORF}, 140 \mathrm{kDa}$, is in reasonable agreement with the size of the larger amylase observed in zymography $(160 \mathrm{kDa})$. Hereafter the protein encoded by the entire ORF is designated the $140 \mathrm{kDa}$ amylase. The amino acid

Table 1. Oligonucleotides used for cloning the B. acidocaldarius amylase

\begin{tabular}{|c|c|c|}
\hline Number & Sequence* & Corresponds to: \\
\hline 371 & 5'CAGTCCTGCTGIGTICCGAAICCIGGGTCGAT 3' & IDPGFGTQQD \\
\hline 393 & 5' CCGGCGCCAAGCCCGTCATCCCCGGCAGG 3' & $\begin{array}{l}5^{\prime} \text { end of the } \mathrm{C} \\
\text { fragment }\end{array}$ \\
\hline 395 & 5' GCTTGTGCCGCAGCCACCGCAGACA 3' & $\begin{array}{l}3^{\prime} \text { end of the } C \\
\text { fragment }\end{array}$ \\
\hline 417 & 5' GGGTTGATCCTGGCTTC $3^{\prime}$ & $\begin{array}{l}5^{\prime} \text { end of the } \mathrm{C} \\
\text { fragment }\end{array}$ \\
\hline 436 & 5' CAAGGGTCTTGAGAGAA 3' & $\begin{array}{l}3^{\prime} \text { end of the } \mathrm{N} \\
\text { fragment }\end{array}$ \\
\hline
\end{tabular}

${ }^{*} \mathrm{I}$, inosine.

Table 2. Similarity of the B. acidocaldarius $140 \mathrm{kDa}$ amylase with certain polysaccharide-degrading enzymes

\begin{tabular}{|c|c|c|c|}
\hline Enzyme, species & $\begin{array}{l}\text { Region in } \\
\text { the } 140 \mathrm{kDa} \\
\text { amylase } \\
\text { (aa) }\end{array}$ & $\begin{array}{c}\text { Identical aa } \\
\text { in the region } \\
(\%)\end{array}$ & Reference \\
\hline $\begin{array}{l}\alpha \text {-Amylase-pullulanase, } \\
\text { C. thermohydrosulfuricum }\end{array}$ & $\begin{array}{l}12-1301 \\
619-1031 \\
619-695 \\
834-907\end{array}$ & $\begin{array}{l}35 \\
49 \\
61 \\
61\end{array}$ & Melasniemi et al. (1990) \\
\hline $\begin{array}{l}\text { Neopullulanase, } \\
\text { B. stearothermophilus }\end{array}$ & $397-1097$ & 36 & Kuriki \& Imanaka (1989) \\
\hline $\begin{array}{l}\text { Maltodextrin glucosidase, } \\
E . \text { coli }\end{array}$ & $383-1106$ & 30 & Tapio et al. (1991) \\
\hline $\begin{array}{l}\text { Cyclodextrin glucanotransferase, } \\
K . \text { pneumoniae }\end{array}$ & $467-1243$ & 26 & Binder et al. (1986) \\
\hline $\begin{array}{l}\alpha \text {-Amylase } \mathrm{C} \\
\text { D. thermophilum }\end{array}$ & $535-1078$ & 25 & Horinouchi et al. (1988) \\
\hline
\end{tabular}



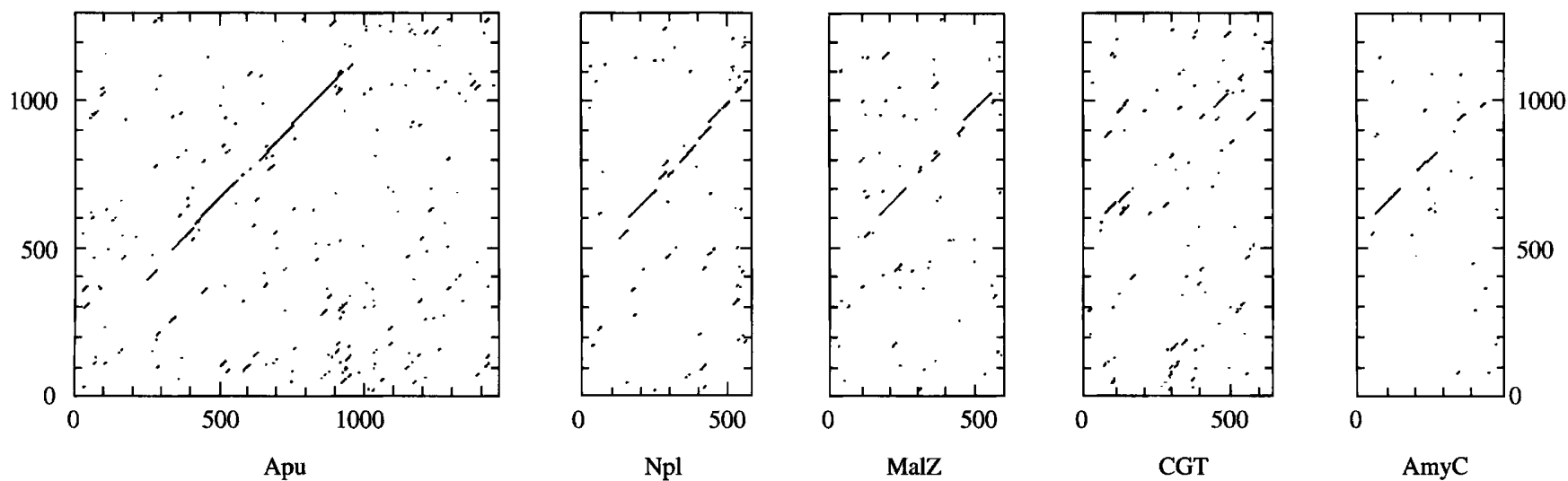

Fig. 4. Comparison of the $B$. acidocaldarius $140 \mathrm{kDa}$ amylase with selected polysaccharide-degrading enzymes. The matrix was generated with the COMPARE program of GCG sequence analysis package (Devereux et al., 1984). The length of stretches compared (window) was 30 aa, and 15 identical aa in the window (stringency) led to a dot. Vertical axes: B. acidocaldarius amylase. Horizontal axes: Apu, $\alpha$-amylase-pullulanase; Npl, neopullulanase; MalZ, maltodextrin glucosidase; CGT, cyclodextrin glucanotransferase; AmyC, $\alpha$-amylase $\mathrm{C}$ (for references see Table 2). The entire sequences have been compared. The numbers along the axes indicate the residues of the sequences.

sequence of the $\mathrm{N}$ terminus from the $92 \mathrm{kDa}$ protein was found within the coding region (at aa 466). It is noteworthy that the eight internal peptides of the $90 \mathrm{kDa}$ amylase were found in this $140 \mathrm{kDa}$ ORF (Fig. 2). There is no putative RBS or promoter upstream from the $\mathrm{N}$ terminus of the $92 \mathrm{kDa}$ amylase, which is consistent with the concept that the smaller amylase may be a cleavage product of the larger. The calculated $\mathrm{pI}$ of $4 \cdot 1$ for both the 92 and $140 \mathrm{kDa}$ proteins was slightly lower than that obtained in experimental analysis of the two amylases (pI 4.8, see above). There is also a putative signal sequence at the $\mathrm{N}$ terminus of the $140 \mathrm{kDa}$ amylase (Fig. 2).

\section{The $140 \mathrm{kDa}$ amylase appears to be $\alpha$-amylase- pullulanase}

The amino acid sequence encoded by the amylase gene was compared with the sequences of the protein database. The search revealed that the $140 \mathrm{kDa}$ protein was similar to several polysaccharide-degrading enzymes (Table 2, Fig. 4). The closest relative was found to be the $\alpha$-amylase-pullulanase (Apu) of Clostridium thermohydrosulfuricum (Melasniemi, 1988; Melasniemi et al., 1990). The region of similarity between these two proteins covers nearly the entire length of both sequences (Table 2, Fig. 4), and there is up to $60 \%$ amino acid identity in two stretches of over 70 aa. It is also noteworthy that the size of the $C$. thermohydrosulfuricum Apu is 1475 aa, i.e. quite close to the size of the $140 \mathrm{kDa}$ amylase (1301 aa). The high degree of similarity between these two proteins suggests that the $140 \mathrm{kDa}$ amylase of $B$. acidocaldarius is $\alpha$-amylase-pullulanase.

When the $B$. acidocaldarius $140 \mathrm{kDa}$ amylase is aligned with the $C$. thermohydrosulfuricum Apu, the homologous

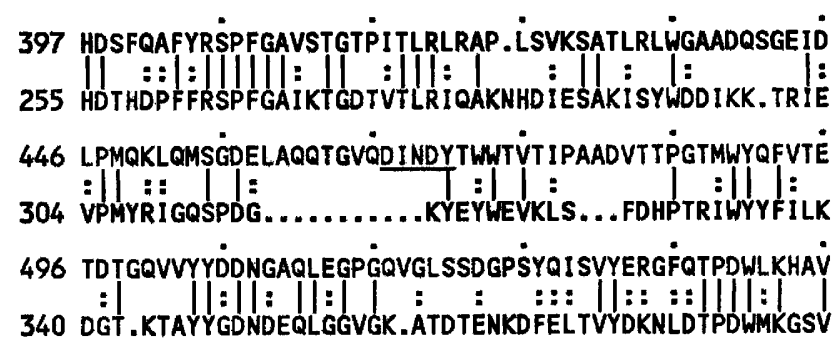

\section{IYEIMPDRFYNGNIATEENPN 566 Amy $: 1: 1111: 11:=$ \\ 388 MYQIFPDRFFNGDSNDHLKK 408 Apu}

Fig. 5. Comparison of the $B$. acidocaldarius $140 \mathrm{kDa}$ amylase (Amy) with $C$. thermohydrosulfuricum Apu (Melasniemi et al., 1990). The region of $B$. acidocaldarius amylase that covers the $\mathrm{N}$ terminus of the $92 \mathrm{kDa}$ amylase is underlined. Identical (|) and closely related (:) amino acids, with a comparison value $\geqslant 0.5$ in the BESTFIT mutation data matrix (Devereux et al., 1984), are indicated.

region continues well beyond the $\mathrm{N}$ terminus of the $92 \mathrm{kDa}$ protein (Figs 4 and 5). Furthermore, the exact $\mathrm{N}$ terminus of the smaller amylase (DINDY) is located in a small gap of the Apu sequence (Fig. 5). Usually the insertions and deletions are located on the surface of a protein (Siezen et al., 1991) which suggests that the $\mathrm{N}$ terminus of the $92 \mathrm{kDa}$ protein may be located in a loop on the surface of the $140 \mathrm{kDa}$ amylase. Therefore this site could be susceptible to some proteases. There are no data available of the proteases of $B$. acidocaldarius, but subtilisin, a common protease in Bacillus spp., cleaves, for example, after Gln (Wells \& Estell, 1988), which is the residue preceding the $\mathrm{N}$ terminus of the $92 \mathrm{kDa}$ protein. Accordingly, the sequence comparison gives further support to the notion that the $92 \mathrm{kDa}$ amylase may be a cleavage product of the $140 \mathrm{kDa}$ amylase.

Part of the $140 \mathrm{kDa}$ protein is similar to several amylases, of which the Dictyoglomus thermophilum $\alpha$ - 
amylase is the most closely related (Table 2). It is noteworthy that the region of similarity (aa 535-1078) is included in the $92 \mathrm{kDa}$ protein, which also has amylase activity even though the specific activity of the $92 \mathrm{kDa}$ protein is lower than that of the $140 \mathrm{kDa}$ amylase (Fig. 1). Except for the Apu protein, no other proteins in the protein sequence databases were found to be similar to the $\mathrm{N}$-terminal region (aa 1-500) of the $B$. acidocaldarius amylase.

\section{Tests to show pullulanase activity}

The observation that the $B$. acidocaldarius $140 \mathrm{kDa}$ amylase was closely related to $C$. thermohydrosulfuricum $\alpha$-amylase-pullulanase motivated us to study whether $B$. acidocaldarius amylase has pullulanase activity. First, we tested whether the cell wash medium of $B$. acidocaldarius plate cultures contains pullulanase activity. A sample of cell wash medium was incubated with pullulan and reduced sugars were detected by the Somogyi-Nelson method. A blue colour was detected which indicated that pullulan was hydrolysed by components present in the sample.

If the $B$. acidocaldarius amylase is also a pullulanase, both enzyme activities would be expected to have similar dependency on temperature: inactivation of the enzyme would cause concomitant loss of both activities. In a crude preparation the effect of temperature on the pullulanase and amylase activities were found to be similar (Fig. 6).

To show that the pullulanase activity observed in the cell wash medium is associated with the amylase, we made further efforts to purify the enzyme. The cell wash medium was fractionated in a Biogel P-100 (Bio-Rad) gel filtration column in $50 \mathrm{mM}-\mathrm{Na}$ acetate buffer $(\mathrm{pH} \mathrm{5})$ and $5 \mathrm{~mm}-\mathrm{CaCl}_{2}$. The pullulan- and starch-degrading activities of the fractions were detected semiquantitatively with pullulanase and amylase plate assays. Both activities were detected in the same fractions (data not shown). These biochemical results are consistent with the concept that the $B$. acidocaldarius amylase also has pullulanase activity, even though the proof is not definite.

The purification of the amylase was hampered by small amounts of the protein. The isolation of the amylase by plate cultures was time-consuming and laborious. Therefore we tested whether the enzyme could be isolated from the supernatant of the liquid culture medium. The liquid culture medium described by Darland \& Brock (1971) was supplemented with 3-5\% soluble starch (Difco) and $0.25 \%$ maltose and the cells were grown in a shaker at $50{ }^{\circ} \mathrm{C}$ for $1-2 \mathrm{~d}$. Amylase activity was released into the culture supernatant; however, the yields were comparable to those in the plate cultivation. It is noteworthy that the $C$. thermohydro-

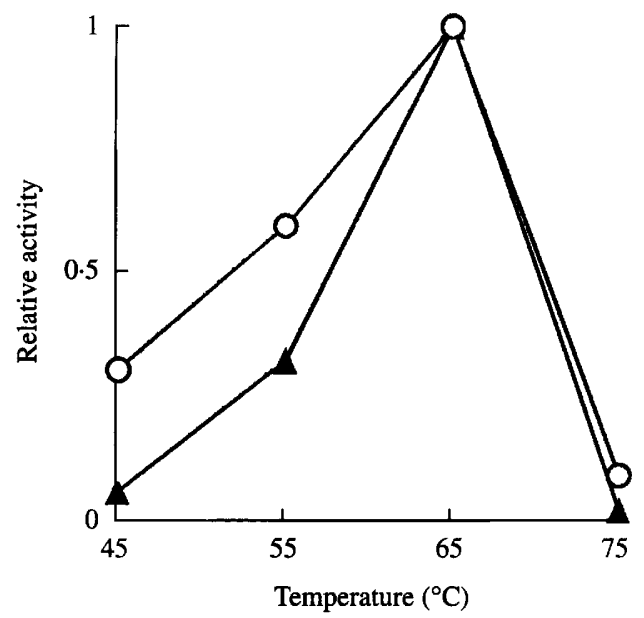

Fig. 6. The effect of temperature an amylase $(O)$ and pullulanase (A) activity released from $\boldsymbol{B}$. acidocaldarius cells. A reaction mixture without enzyme was used as a blank. For pullulanase, the relative activity of 1.0 corresponds to $A_{500}=0.56$, and for amylase $A_{620}=2.58$. The samples were incubated for $4 \mathrm{~h}$ (amylase) and $8 \mathrm{~h}$ (pullulanase).

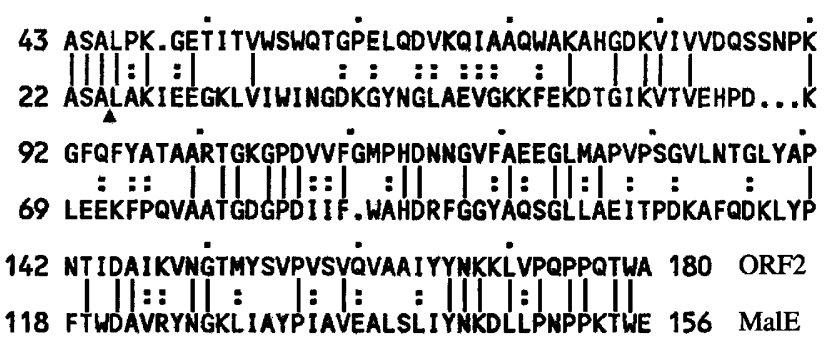

Fig. 7. Comparison of the ORF2 product with E. coli MalE (Duplay et al., 1984). The signal sequence cleavage site of MalE is indicated by an arrowhead. The alignment shows a score of 12 when the statistical significance of the alignment is evaluated by the PCOMPARE program of PCGENE. A score of $3 \mathrm{SD}$ indicates that the odds for obtaining the alignment by chance are less than 1 in 1000 (Feng et al., 1985). Identical (|) and closely related (:) amino acids are indicated.

sulfuricum Apu is released to the culture medium, or associated with the cell surface, depending on the type of carbon source used in the medium (Melasniemi, 1987). The sequence of the $B$. acidocaldarius amylase does not reveal any membrane-anchoring sequence, suggesting an association with the cell wall rather than hydrophobic attachment with the cytoplasmic membrane.

ORF2 is homologous with the maltose-binding protein of E. coli

There is an ORF, ORF2, downstream from the amylase gene (Fig. 2). ORF2 lacks the 3'-terminal region of the putative gene. There are two possible RBSs upstream from the putative initiation codon (ATG at $7332 \mathrm{bp}$ ). The protein encoded by ORF 2 has significant similarity to MalE, the maltose-binding protein of $E$. coli (Fig. 7). In $E$. coli MalE is a periplasmic protein which partici- 
pates in maltose transport (Hengge \& Boos, 1983; Spurlino et al., 1991). There is no promoter nor transcription terminator in the region between the amylase gene and ORF2 which suggests that the MalE homologue may belong to the same operon with the amylase gene. E. coli MalE contains a signal sequence, whereas there is no typical signal sequence in the $N$ terminus of ORF2. It seems possible that the ORF2 protein is bound to the cell membrane of $B$. acidocaldarius and participates in the transport of maltose into the cell. To our knowledge there are no previous reports indicating the location of a maltose transport component in a same operon with amylase.

\section{An attempt to express the amylase gene in $B$. subtilis}

Our preliminary attempt to express the amylase gene in $B$. subtilis was not successful. The entire gene was assembled for expression into the pHP13 vector (Haima et al., 1987). pHP13 has low copy number in Bacillus which should minimize possible instability caused by the long insert and the large protein. The plasmid, which contained the gene for the $140 \mathrm{kDa}$ amylase was transformed to $B$. subtilis BRB152 (Sibakov \& Palva, 1984) but no starch-degrading activity was detected. Yet, the plasmid had suffered no obvious rearrangements according to restriction enzyme digestions. The inability of $B$. subtilis to produce the enzyme may be caused by several reasons. For example, the promoter may be nonfunctional in $B$. subtilis, or the enzyme may fold incorrectly at low temperature $\left(37^{\circ} \mathrm{C}\right)$ and neutral $\mathrm{pH}$ $(\mathrm{pH} 7)$ used in the cultivation.

\section{Conclusions}

The gene encoding an amylase from $B$. acidocaldarius was cloned and the encoded protein was found to be closely related to the $\alpha$-amylase-pullulanase of $C$. thermohydrosulfuricum. It was concluded from the sequence data, with some support from experimental data, that the cloned gene encodes $\alpha$-amylasepullulanase. We have been unable to purify the $140 \mathrm{kDa}$ protein, the product of the cloned gene; yet, all the data are consistent with the concept that the $140 \mathrm{kDa}$ protein is identical with the $160 \mathrm{kDa}$ protein first observed in zymography, and the $92 \mathrm{kDa}$ amylase is a cleavage product of this large protein. The $92 \mathrm{kDa}$ protein appears to have lower amylase activity than the $140 \mathrm{kDa}$ protein.

Note added in proof. The $160 \mathrm{kDa}$ amylase of B. acidocaldarius ATCC 27009 has recently been purified. The $160 \mathrm{kDa}$ amylase degrades pullulan with a rate that is approximately 100 -fold lower than the rate of degradation of soluble starch (B. Brockschmidt \&
E. P. Backer, University of Osnabrück, FRG, personal communication).

The authors are grateful to Dr Lars Paulin for the synthesis of oligonucleotides, and to Mrs Merja Turunen for excellent technical assistance. This work was supported by Genesit Ltd and by a grant from The Foundation for Biotechnical and Industrial Fermentation Research (T.K.).

\section{References}

Binder, F., HubER, O. \& Böck, A. (1986). Cyclodextringlucosyltransferase from Klebsiella pneumoniae M5a1: cloning, nucleotide sequence and expression. Gene 47, 269-277.

Boyer, E. W., Ingle, M. B. \& Mercer, G. D. (1979). Isolation and characterization of unusual bacterial amylases. Starch Stärke 31, $166-171$.

Buonocore, V., Caporale, C., De Rosa, M. \& Gambacorta, A. (1976). Stable, inducible thermoacidophilic $\alpha$-amylase from Bacillus acidocaldarius. Journal of Bacteriology 128, 515-521.

DARLAND, G. \& BROCK, T. D. (1971). Bacillus acidocaldarius sp. nov., an acidophilic thermophilic spore-forming bacterium. Journal of General Microbiology 67, 9-15.

DeVereuX, J., Haeberli, P. \& Smithies, O. (1984). A comprehensive set of sequence analysis programs for the VAX. Nucleic Acids Research 12, 387-395.

Duplay, P., Bedouelle, H., Fowler, A., Zabin, I., Saurin, W. \& HoFNuNG, M. (1984). Sequences of the malE gene and its product, the maltose-binding protein of Escherichia coli K12. Journal of Biological Chemistry 259, 10606-10613.

Feng, D. F., Johnson, M. S. \& Doolittle, R. F. (1985). Aligning amino acid sequences: comparison of commonly used methods. Journal of Molecular Evolution 21, 112-125.

Haima, P., Bron, S. \& Venema, G. (1987). The effect of restriction on shotgun cloning and plasmid stability in Bacillus subtilis Marburg. Molecular and General Genetics 209, 335-342.

HENGGE, R. \& Boos, W. (1983). Maltose and lactose transport in Escherichia coli. Examples of two different types of concentrative transport systems. Biochimica et Biophysica Acta 737, 443-478.

Horinouchi, S., Fukusumi, S., OHSHIMA, T. \& BePPU, T. (1988). Cloning and expression in Escherichia coli of two additional amylase genes of a strictly anaerobic thermophile, Dictyoglomus thermophilum. European Journal of Biochemistry 176, 243-253.

KALKKINEN, N. (1986). Radio-sequence analysis: an ultra-sensitive method to align protein and nucleotide sequences. In Advanced Methods in Protein Microsequence Analysis, pp. 194-206. Edited by B. Wittmann-Liebold, J. Salnikow \& V. A. Erdman. Berlin, Heidelberg: Springer-Verlag.

Kalkkinen, N. \& TilgmanN, C. (1988). A gas-pulsed-liquid-phase sequencer constructed from a Beckman $890 \mathrm{D}$ instrument by using Applied Biosystems delivery and cartridge blocks. Journal of Protein Chemistry 7, 242-243.

KANNo, M. (1986). A Bacillus acidocaldarius $\alpha$-amylase that is highly stable to heat under acidic conditions. Agricultural and Biological Chemistry 50, 23-31.

Koivula, T., Sibakov, M. \& Palva, I. (1991). Isolation and characterization of Lactococcus lactis subsp. lactis promoters. Applied and Environmental Microbiology 57, 333-340.

KURIKI, T. \& ImANAKA, T. (1989). Nucleotide sequence of the neopullulanase gene from Bacillus stearothermophilus. Journal of General Microbiology 135, 1521-1528.

LAEMMLI, U. K. (1970). Cleavage of structural proteins during the assembly of the head of bacteriophage T4. Nature, London 227, 680-685.

MARMUR, J. (1961). A procedure for the isolation of deoxyribonucleic acid from microorganisms. Journal of Molecular Biology 3, 208-218.

MELASNIEMI, H. (1987). Effect of carbon source on production of thermostable $\alpha$-amylase, pullulanase and $\alpha$-glucosidase by Clostridium thermohydrosulfuricum. Journal of General Microbiology 133, 883-890. 
Melasniemi, H. (1988). Purification and some properties of the extracellular $\alpha$-amylase-pullulanase produced by Clostridium thermohydrosulfuricum. Biochemical Journal 250, 813-818.

Melasniemi, H., Paloheimo, M. \& Hemiö, L. (1990). Nucleotide sequence of the $\alpha$-amylase-pullulanase gene from Clostridium thermohydrosulfuricum. Journal of General Microbiology 136, 447-454.

Mozdzanowski, J. \& SPeicher, D. W. (1990). Quantitative electrotransfer of proteins from polyacrylamide gels onto PVDF membranes. In Current Research in Protein Chemistry, pp. 87-93. Edited by J. Villafranca. New York: Academic Press.

NeLSON, N. (1944). A photometric adaptation of the Somogyi method for the determination of glucose. Journal of Biological Chemistry 153, 375-380.

PEARson, W. R. \& LiPMAN, D. J. (1988). Improved tools for biological sequence comparison. Proceedings of the National Academy of Sciences of the United States of America 85, 2444-2448.

Sakano, Y., Sano, M. \& Kobayashi, T. (1985). Hydrolysis of $\alpha-1,6-$ glucosidic linkages by $\alpha$-amylases. Agricultural and Biological Chemistry 49, 3041-3043.

Sambrook, J., Fritsch, E. F. \& Maniatis, T. (1989). Molecular Cloning: a Laboratory Manual, 2nd edn. Cold Spring Harbor, NY: Cold Spring Harbor Laboratory.

SANGER, F., Nicklen, S. \& Coulson, A. R. (1977). DNA sequencing with chain-terminating inhibitors. Proceedings of the National Academy of Sciences of the United States of America 74, 5463-5467.

Sibakov, M. \& Palva, I. (1984). Isolation and the 5'-end nucleotide sequence of Bacillus licheniformis $\alpha$-amylase gene. European Journal of Biochemistry 145, 567-572.

Siezen, R. J., De Vos, W. M., Leunissen, J. A. M. \& Dijkstra, B. W. (1991). Homology modelling and protein engineering strategy of subtilases, the family of subtilisin-like serine proteases. Protein Engineering 4, 719-737.

SOMOGYI, M. (1952). Notes on sugar determination. Journal of Biological Chemistry 195, 19-23.

Spurlino, J. C., Lu, G. Y. \& Quiocho, F. A. (1991). The 2·3-Å resolution structure of the maltose- or maltodextrin-binding protein. Journal of Biological Chemistry 266, 5202-5219.

TAPIO, S., Yeh, F., Shuman, H. A. \& Boos, W. (1991). The malZ gene of Escherichia coli, a member of the maltose regulon, encodes a maltodextrin glucosidase. Journal of Biological Chemistry 266, 19450-19458.

Uchino, F. (1982). A thermophilic and unusually acidophilic amylase produced by a thermophilic acidophilic Bacillus sp. Agricultural and Biological Chemistry 46, 7-13.

VIHINEN, M. \& MÄNTSÄLÄ, P. (1989). Microbial amylolytic enzymes. Critical Reviews in Biochemistry and Molecular Biology 24, 329-418.

Wells, J. A. \& Estell, D. A. (1988). Subtilisin - an enzyme designed to be engineered. Trends in Biochemical Sciences 13, 291-297.

Wisotzkey, J. D., Jurtshuk, P., Fox, G. E., Deinhard, G. \& Poralla, K. (1992). Comparative sequence analysis on the $16 \mathrm{~S}$ rRNA (rDNA) of Bacillus acidocaldarius, Bacillus acidoterrestris, and Bacillus cycloheptanicus and proposal for creation of a new genus, Alicyclobacillus gen. nov. International Journal of Systematic Bacteriology 42, 263-269. 